\title{
ESTIMATON OF MAXIMUM SHORT-TERM PRECIPITATION OVER THE RIJEKA REGION
}

\author{
Marjana Gajić-Čapka \\ Meteorological and Hydrological Service of Croatia, Ph.D. \\ Nevenka Ožanić \\ University of Rijeka, Faculty of Civil Engineering, Associate Professor \\ Corresponding author: nozanic@gradri.uniri.hr \\ Nino Krvavica \\ University of Rijeka, Faculty of Civil Engineering, mag.ing.aedif.
}

\begin{abstract}
In this paper, we considered the occurrence of extreme short-term rainfall in the region of Rijeka city, analyzed the extreme values, and commented on application of the results. We estimated the maximum precipitation amounts for different occurrence probabilities (return periods) for time intervals of $5,10,20,30,40$, and 60 minutes, as well as 2, 4, 8, 12 and 24 hours, using data taken at the Rijeka meteorological station over periods of 1958-2011 and 1958-2012. Additionally, we evaluated the extremity of a heavy rainfall event that affected the city of Rijeka on September 12th, 2012. Using absolute extremes recorded for time intervals of 20 minutes to 2 hours, we accounted for precipitation peaks to calculate new intensity-duration-return period curves for Rijeka. In this way, we revised the precipitation input parameters used to plan and design urban drainage systems. This revision included significant changes for durations of 20, 30, and 40 minutes, for which the amounts recorded on September 12th, 2012 had return periods of longer than 100 years.
\end{abstract}

Keywords: precipitation, short-term extreme precipitation, extreme value analysis, IDF curves, Rijeka

\section{PROCJENA MAKSIMALNIH KRATKOTRAJNIH OBORINA NA RIJEČKOM PODRUČJU}

Sažetak: U radu je razmatrana problematika pojavljivanja kratkotrajnih intenzivnih oborina na riječkom području, analiza ekstremnih vrijednosti te primjena rezultata. Proračunani su očekivani maksimumi količine oborina za različite vjerojatnosti pojavljivanja (povratna razdoblja) za odabrane vremenske intervale (trajanja) od 5, 10, 20, 30, 40 i 60 minuta, te 2, 4, 8, 12 i 24 sata, prema podatcima za 1958. - 2011. i 1958. - 2012., s meteorološke postaje Rijeka. Ocijenjena je ekstremnost jake kišne epizode zabilježene u Rijeci 12. rujna 2012. Apsolutni ekstremi zabilježeni su za trajanja od $20 \mathrm{~min}$ do 2 sata. Uvažavajući te zabilježene maksimume oborine, promjene u procjenama maksimuma su uglavnom pozitivne i za povratna razdoblja dulja od 20 godina i intervale od 20 minuta do 12 sati iznose 5 do $13 \%$. Definirane su i nove ITP (intenzitet - trajanje - povratno razdoblje) krivulje za Rijeku, čime su novelirani ulazni oborinski parametri za potrebe projektiranja sustava oborinske odvodnje. Najznačajnije promjene su primjetne za intenzitete trajanja 20, 30 i 40 min, za koje količine oborine, pale 12. rujna 2012. godine, ukazuju na povratno razdoblje veće od 100 godina.

Ključne riječi: oborina, kratkotrajne intenzivne oborine, analiza ekstremnih vrijednosti, ITP krivulje, Rijeka 


\section{INTRODUCTION}

Along the Croatian Adriatic coast, hazardous weather events can endanger the population and cause significant damage. These events include wind storms and extremes of precipitation, including floods, flash floods, and droughts [1]. Abundant precipitation is often related to cyclones and atmospheric fronts that pass through the region. Sometimes these fronts are generated or intensified in the north Adriatic, but they can be strongly influenced by local orographic factors, most often the Dinaric Alps, which stretch along the north-eastern Adriatic coast [2].

Understanding and predicting precipitation in a certain region is very important not only in the scientific and professional circles but also in human activities that depend on meteorological conditions, including civil engineering, agriculture, transportation, and tourism. Most information on precipitation comes from ground measurements at meteorological stations. Unfortunately, the spatial density of these stations is insufficient, leading to difficulties in analyzing spatial precipitation, especially for precipitation episodes within limited area. Of all types of precipitation, heavy short-term precipitation intensities are the most variable parameter in time. Heavy short-term precipitation refers to rain lasting up to 24 hours of intensities that rarely occur [3].

In hydraulic engineering, the most important input in calculations related to urban drainage systems is meteorological data on regional precipitation, focusing on heavy short-term precipitation and their intensities. The precipitation intensity is a secondary parameter, derived from the precipitation amount. To calculate the precipitation amount, data on liquid precipitation is measured in a rain gauge over a set time interval; in the present work, the interval was 5 minutes. One characteristic of short-term precipitation is its spatial inhomogeneity and non-stationarity, which makes it difficult to assess and model surface drainage. This issue is especially true in regions with prominent orography and large precipitation gradients, such as the Rijeka region and its surroundings. This region also has among the highest precipitation intensities in Croatia $[4,5]$.

When calculating hydrological parameters in models of surface drainage, the intensity of heavy short-term rainfall is often the only parameter that is both variable and locally measurable. However, there is currently not enough reliable rainfall data for Croatia and the Rijeka region for analysis. There are no regional spatial analyses of short-term, heavy rainfall in these areas, and the accuracy and availability of intensity-duration-frequency (IDF) curves from ombrographic stations with longer recording periods are questionable.

This paper analyzes the longest available series of ombrographic data for the Rijeka region, recorded at the meteorological station in Rijeka starting in 1958. We estimated the maximum precipitation amounts for different time intervals (durations) and occurrence probabilities (return periods) using data from the time periods of 19582011 and 1958-2012. Using these results, we assessed the extremity of a heavy rainfall episode in Rijeka on September 12th, 2012, which produced a precipitation amount of $208.3 \mathrm{~mm}$ over 24 hours. Most of the precipitation fell during 6 hour interval $(181.5 \mathrm{~mm})$ with extraordinary amounts that were recorded in the very short intervals of $20 \mathrm{~min}(46.7 \mathrm{~mm})$ to $40 \mathrm{~min}(74.8 \mathrm{~mm})$. This extreme rainfall flooded the city of Rijeka, where most roads became watercourses. By analyzing the recorded maximum precipitation quantities in September 2012, we defined new IDF curves for Rijeka and updated the input precipitation parameters used to plan and design hydraulic engineering systems.

\section{STATISTICAL ANALYSIS OF MAXIMUM SHORT-TERM PRECIPITATION EVENTS IN RIJEKA}

\subsection{Precipitation recording and processing in Rijeka}

The main meteorological station in Rijeka has operated since 1954 within the station network of the Meteorological and Hydrological Service of Croatia (DHMZ). This station has continuously recorded precipitation events since 1958, and the present work used the 1958-2012 data, excluding 1965 because of insufficient data. Several other ombrographs have been active in the wider Rijeka region and its surroundings, but only provide data over narrower time periods.

Over the last 50 years, there have been several analyses of heavy short-term rainfall in the urban area of Rijeka. The precipitation characteristics of this area was thoroughly analyzed in 2008 [6], and this study stated that the first known analysis of short-term rainfall in Rijeka was conducted in 1967. A study of sewage systems in Rijeka [7] analyzed occurrences of heavy short-term rainfall from 1957 to 1998, assessing durations from 10 
minutes to 24 hours, and calculating the maximum quantities and intensities of rainfall by using the generalized extreme value distribution (GEV) for durations of $10,20,30,40$, and $60 \mathrm{~min}$, and 2, 4, 8, 12, and $24 \mathrm{~h}$, as well as IDF curves. In 2002, the previous IDF curves have been corrected and adjusted, using several equalization functions and adopting functions with a larger correlation coefficient, for durations of up to and greater than 2 hours for all return periods. [8]

Extreme rainfall is characterized not only by its duration but also by the behavior of precipitation in the studied region. From climatological and statistical perspectives, the rainfall is defined by the distribution of precipitation falling over various time intervals (e.g., a day, an hour, or a shorter interval). Thereby, series of annual maximum values of observed precipitation parameters (e.g., for a GEV distribution) or series of exceeded thresholds (e.g., for a general Pareto distribution) can be analyzed. In practice, Croatian hydrological studies use precipitation empirical thresholds (lower limits), which are used for secondary analyses. For Rijeka, the thresholds selected were $5.4 \mathrm{~mm}$ over 10 minutes, $10.5 \mathrm{~mm}$ over 60 minutes, and $50 \mathrm{~mm}$ over 24 hours (Table 1). Figure 1 compares the height-density-frequency (HDF) curves for Zagreb-Grič and Rijeka [9]. The precipitation amounts over a given return period are much lower in the continental region (Zagreb) than in the coastal region with highly developed orography (Rijeka). Furthermore, the return values for a 2-year return period for Rijeka almost coincides with a 100-year period for Zagreb, which emphasizes that a given precipitation events can be extreme in one region of Croatia, but regular in another.

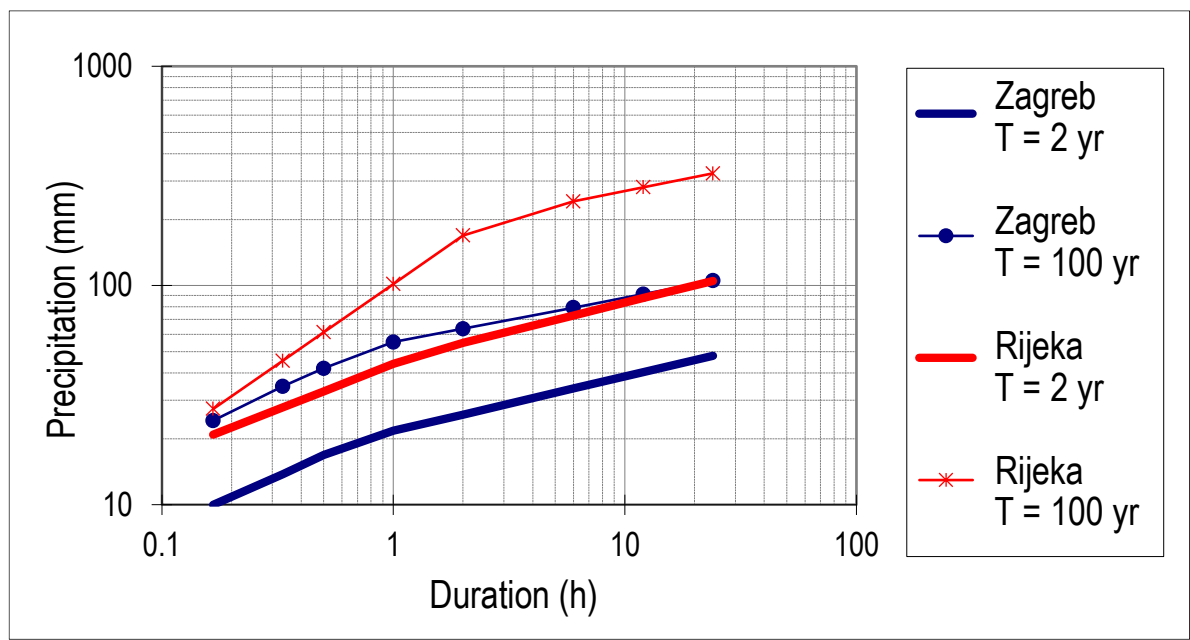

Figure $1 \mathrm{HDF}$ curves for return periods of 2 years and 100 years, calculated using data from rain gauges at the Zagreb-Grič and Rijeka meteorological stations [9]

\subsection{Data and method}

Analysis of extreme short-term precipitation amounts in Croatia shows that a very long data series (50 to 80 years) is required for climatologically reliable assessments of heavy short-term rainfall (from 10 minutes to 24 hours) [10]. Thus, in this paper we analyzed extreme short-term precipitation amounts based on rainfall data from time periods of 1958-2011 and 1958-2012, taken at the main meteorological station Rijeka $(\mathrm{H}=120 \mathrm{~m} \mathrm{~nm}, \varphi=$ $\left.45^{\circ} 20^{\prime} 13^{\prime \prime}, \lambda=14^{\circ} 26^{\prime} 34^{\prime \prime}\right)$. These data include the maximum annual precipitation amounts for intervals of 5,10 , $20,30,40$, and $60 \mathrm{~min}$, as well as for $2,4,8,12$ and $24 \mathrm{~h}$. We calculated the expected maximum precipitation amounts over the same intervals for different return periods (i.e., the occurrence probability) with the GEV distribution by using the annual maximum series $[11,12,13]$. Given the length of the data series, reliable assessments [14] can be realistically obtained by assessing return periods of up to twice the length of the original series. These estimates of maximum precipitation amounts can also be used in designing hydraulic engineering structures [15-17]. We calculated the assessments of distribution parameters by the maximum value method, using recorded series of the annual maximum precipitation amounts. We also assessed the extremity of the measured amounts over various time intervals during each observed rainy episode by comparing the maximum values for different return periods, calculated with the GEV distribution applied to the 1958-2011 data. 


\subsection{Annual cycle of heavy short-term precipitation amounts}

Heavy rainfall events are common over the wider area of Rijeka. From an analysis of maximum daily precipitation amounts in the Climate Atlas of Croatia [18], heavy rainfall events appear mostly from June to November, when they can cause major floods. We analyzed the frequency of the maximum short-term precipitation amounts lasting from 10 minutes to 24 hours in Rijeka. Table 1 shows the annual cycle of precipitation amounts; $n_{y r}$ is the mean annual number (frequency) of rainfall events when the amount for a particular duration is higher than the given empirical threshold for Rijeka used in hydrological practice. The numbers in cells stand for the average monthly frequency. The field coloration represents the relative frequency (\%) for each duration per month according to the legend attached below the table. On average, heavy rainfall for durations up to 60 minutes appears annually 15 to 22 times, mostly in September (about 4 cases) and in October (about 3 to 4 cases). For durations of 2 and 4 hours, the annual averages are 28 and 29 cases, respectively, with about 4 occurrences per month from September to November. Heavy long-term precipitation amounts often occur in October and November.

Table 1 Annual cycle in precipitation amount above the empirical thresholds as a function of event duration and month (1-12) for Rijeka in 1958-2012.

\begin{tabular}{|c|c|c|c|c|c|c|c|c|c|c|c|c|c|c|}
\hline time & threshold & $\boldsymbol{n}_{\mathbf{y r}}$ & $\mathbf{1}$ & $\mathbf{2}$ & $\mathbf{3}$ & $\mathbf{4}$ & $\mathbf{5}$ & $\mathbf{6}$ & $\mathbf{7}$ & $\mathbf{8}$ & $\mathbf{9}$ & $\mathbf{1 0}$ & $\mathbf{1 1}$ & $\mathbf{1 2}$ \\
\hline 10 $\mathrm{min}$ & 5.4 & 14.9 & 0.2 & 0.0 & 0.1 & 0.3 & 0.6 & 1.9 & 1.6 & 2.4 & 3.7 & 2.5 & 1.2 & 0.3 \\
\hline $20 \mathrm{~min}$ & 7.4 & 16.9 & 0.3 & 0.1 & 0.2 & 0.5 & 0.8 & 2.0 & 1.7 & 2.5 & 3.9 & 2.7 & 1.6 & 0.6 \\
\hline $30 \mathrm{~min}$ & 8.4 & 18.8 & 0.4 & 0.2 & 0.3 & 0.6 & 0.9 & 2.1 & 1.8 & 2.6 & 4.0 & 3.1 & 2.0 & 0.8 \\
\hline $40 \mathrm{~min}$ & 9.0 & 20.9 & 0.5 & 0.3 & 0.4 & 0.9 & 1.2 & 2.4 & 1.9 & 2.8 & 4.2 & 3.3 & 2.1 & 0.9 \\
\hline $50 \mathrm{~min}$ & 9.6 & 21.7 & 0.6 & 0.3 & 0.5 & 1.0 & 1.2 & 2.4 & 1.8 & 2.7 & 4.2 & 3.5 & 2.3 & 1.2 \\
\hline 60 min & 10.5 & 20.9 & 0.7 & 0.3 & 0.6 & 0.9 & 1.2 & 2.3 & 1.6 & 2.4 & 4.0 & 3.4 & 2.3 & 1.2 \\
\hline 2 sata & 12.0 & 28.0 & 1.5 & 0.8 & 1.3 & 1.4 & 1.6 & 2.7 & 1.6 & 2.6 & 4.2 & 4.3 & 3.5 & 2.5 \\
\hline 4 sata & 15.0 & 29.0 & 2.1 & 1.6 & 1.7 & 1.7 & 1.6 & 2.3 & 1.5 & 2.2 & 3.7 & 4.0 & 3.7 & 3.0 \\
\hline 6 sati & 20.0 & 21.7 & 1.6 & 1.2 & 1.3 & 1.2 & 1.3 & 1.5 & 1.0 & 1.5 & 2.8 & 3.2 & 2.8 & 2.4 \\
\hline 12 sati & 30.0 & 14.4 & 1.3 & 0.9 & 0.8 & 0.8 & 0.7 & 0.9 & 0.6 & 0.9 & 1.8 & 2.0 & 2.0 & 1.7 \\
\hline 18 sati & 40.0 & 9.7 & 0.9 & 0.5 & 0.6 & 0.4 & 0.5 & 0.6 & 0.4 & 0.6 & 1.3 & 1.4 & 1.3 & 1.2 \\
\hline 24 sata & 50.0 & 6.6 & 0.6 & 0.3 & 0.4 & 0.2 & 0.3 & 0.3 & 0.1 & 0.4 & 0.9 & 1.1 & 1.1 & 0.9 \\
\hline
\end{tabular}

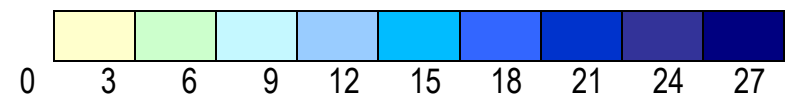

\subsection{Analysis of rain episode from September 12-13, 2012}

In the late evening hours of September 12th, 2012 a strong storm affected the Rijeka region and the mountain hinterland. Figure 2 shows the spatial distribution of daily rainfall on September 13th, 2012 at 7 am, recorded at stations in the Meteorological and Hydrological Service of Croatia network. Using the ombrograph data at the Rijeka meteorological station (Kozala), Figure 3 presents a more detailed inspection of this rainfall event over its duration. In this event, $208.3 \mathrm{~mm}$ of rain fell within 24 hours, and $200.9 \mathrm{~mm}$ of this fell over 12 hours. The strongest rainfall intensity over 1 hour was $86.4 \mathrm{~mm}$. The rain episode occurring over 6 hours, from $6 \mathrm{pm}$ until midnight, peaked between 9 and $11 \mathrm{pm}$. The maximum amounts over 20,30, 40, 50,60, and 120 minutes, which were part of the peak of the rain episode, have not been recorded in Rijeka since recording began in 1958 (Table 2). 


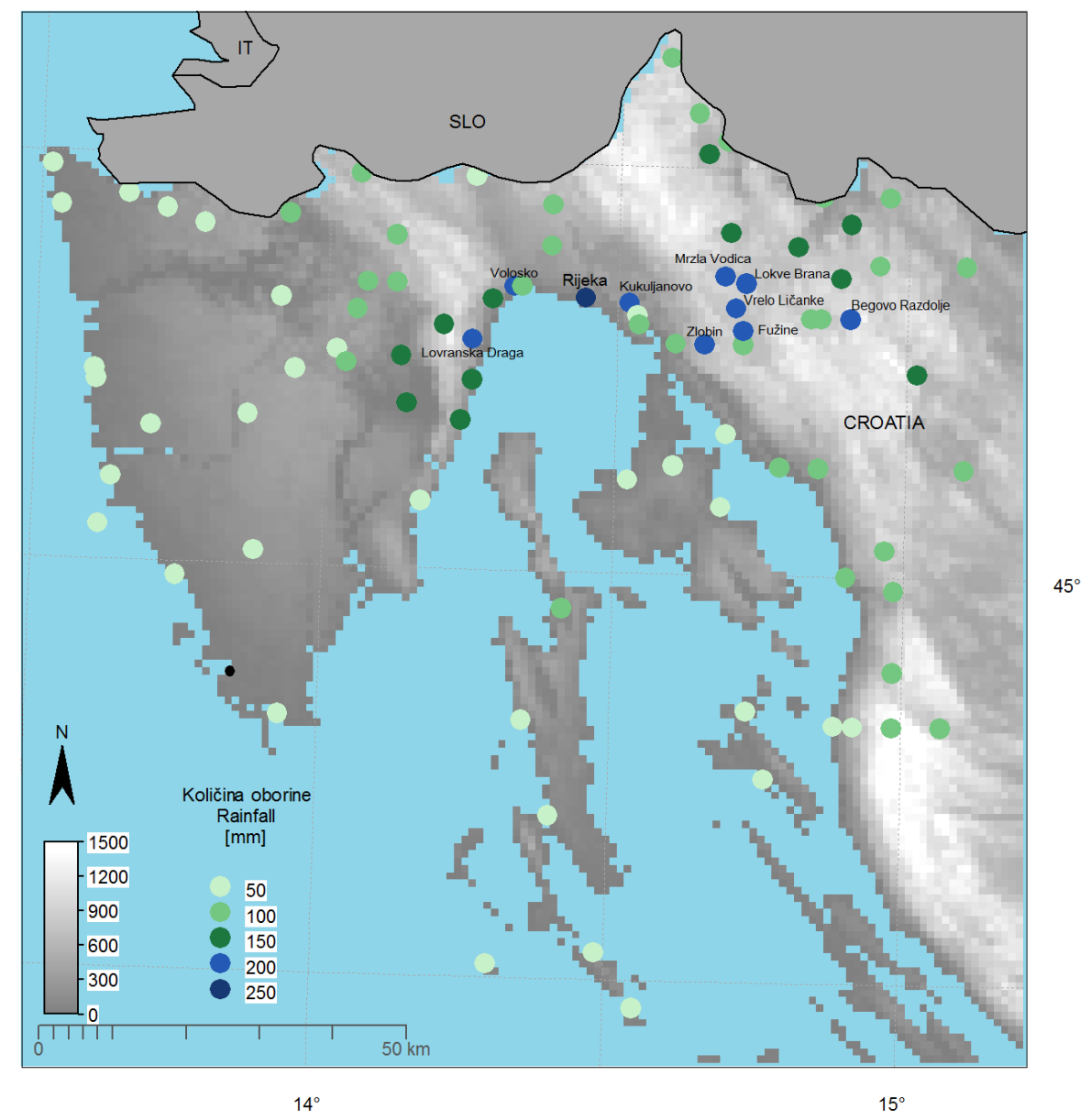

Figure 2 Daily precipitation amounts in the wider Rijeka region on September $13^{\text {th }}, 2012$ at 7 am Source of data: Meteorological and Hydrological Service of Croatia. (Author: mr.sc. Melita Perčec Tadić)

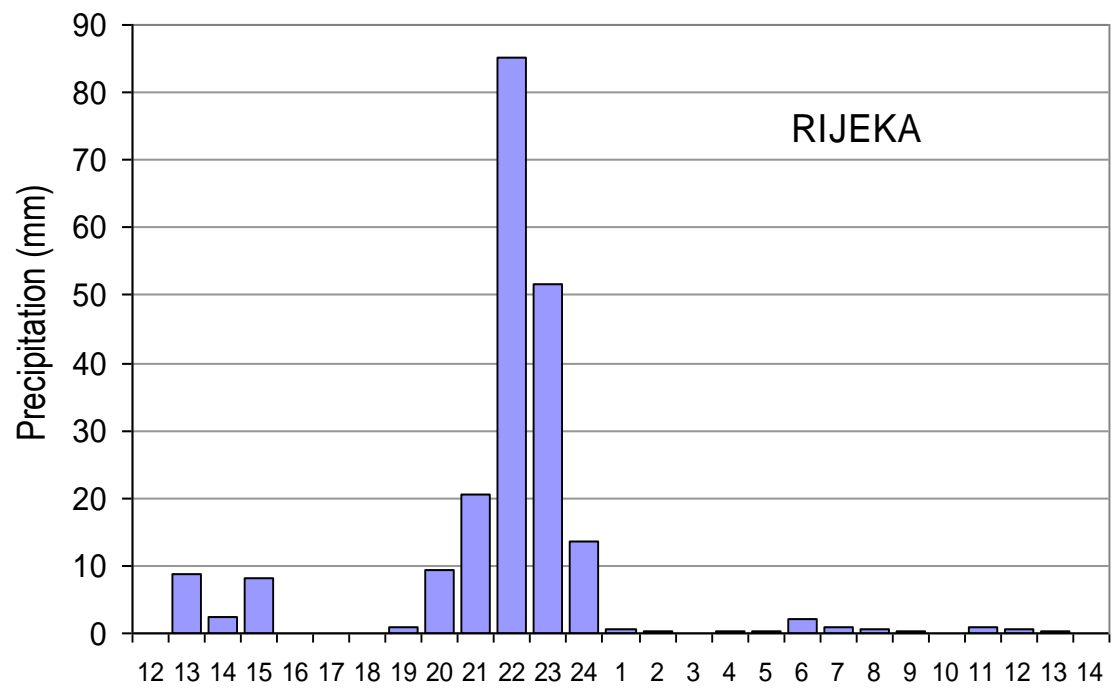

September 12-13, 2012 / Time (h)

Figure 3 Hourly precipitation amounts from 1 pm on September $12^{\text {th }}, 2012$ until 1 pm on September 13th, 2012 according to ombrographic data at the Rijeka meteorological station 
Table 2 Annual maximum precipitation amounts $\left(R_{\max }\right)$ recorded over different intervals $(t)$ during 1958 2011, compared to the rain event on September $12^{\text {th }}, 2012$ in Rijeka, and the associated return periods T according to the GEV distribution applied to the 1958-2011 and 1958-2012 data series

\begin{tabular}{|c|c|c|c|c|c|}
\hline \multirow[t]{2}{*}{$t$} & \multicolumn{2}{|c|}{ 1958-2011 } & \multirow{2}{*}{$\begin{array}{c}\text { 12th September } \\
R(\mathrm{~mm})\end{array}$} & \multirow{2}{*}{$\begin{array}{c}T_{1958-2011} \\
\text { (year) }\end{array}$} & \multirow{2}{*}{$\begin{array}{c}T_{1958-2012} \\
\text { (year) }\end{array}$} \\
\hline & $R_{\max }(\mathrm{mm})$ & $T$ (year) & & & \\
\hline $5 \mathrm{~min}$ & 19.3 & 50 & 14.5 & 7 & 7 \\
\hline $10 \mathrm{~min}$ & 29.2 & 54 & 24.6 & 12 & 13 \\
\hline $20 \mathrm{~min}$ & 40.2 & 63 & 46.7 & $>1000$ & 135 \\
\hline $30 \mathrm{~min}$ & 55.5 & 69 & 63.7 & 415 & 96 \\
\hline $40 \mathrm{~min}$ & 67 & 48 & 74.8 & 130 & 68 \\
\hline $50 \mathrm{~min}$ & 77.8 & 40 & 80.8 & 62 & 41 \\
\hline $60 \mathrm{~min}$ & 86.4 & 40 & 87.4 & 43 & 33 \\
\hline $2 \mathrm{~h}$ & 138.9 & 38 & 141.1 & 40 & 31 \\
\hline $4 \mathrm{~h}$ & 194.9 & 80 & 171.8 & 52 & 39 \\
\hline $6 \mathrm{~h}$ & 252.5 & 103 & 181.5 & 36 & 31 \\
\hline $12 \mathrm{~h}$ & 317.3 & 214 & 200.9 & 37 & 30 \\
\hline $18 \mathrm{~h}$ & 324.7 & 228 & 205.3 & 29 & 26 \\
\hline $24 \mathrm{~h}$ & 324.7 & 232 & 208.3 & 25 & 22 \\
\hline
\end{tabular}

The rainfall storm quickly paralyzed the whole city and flooded the majority of city streets. Manholes overflowed along roads in the city and in the surrounding area, and the storm precipitated several slides and large deposits of gravel and other materials, flooded cellars and ground floor spaces. Moreover, it completely flooded and sunk the recently set lawn of the Kantrida football stadium (Figure 4).
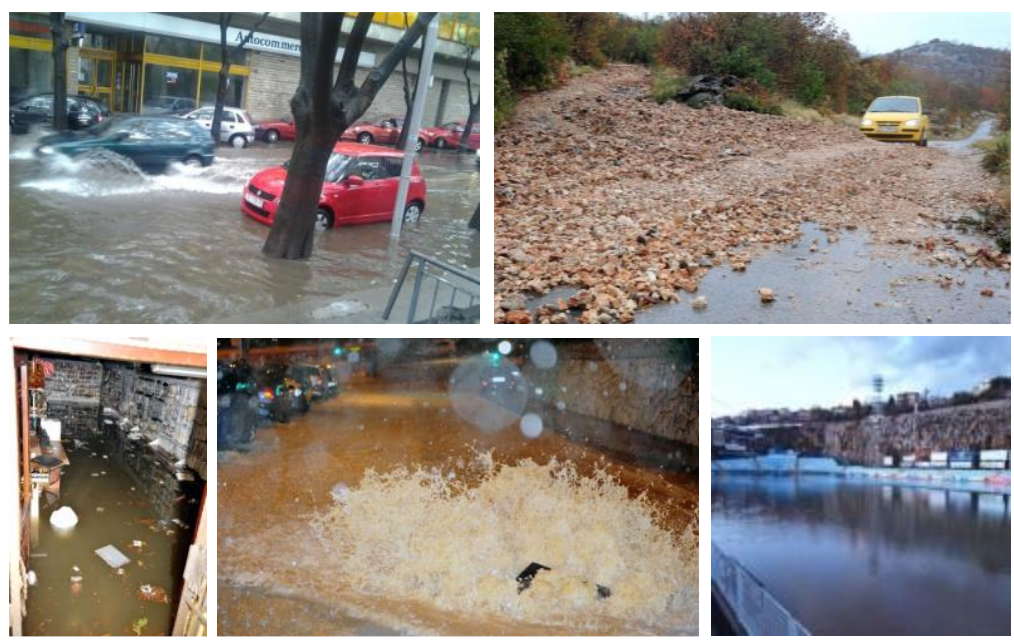

Figure 4 Consequences of the storm in the Rijeka region on September $12^{\text {th }}, 2012 .[19]$

Figure 5 shows the annual short-term precipitation amounts according to the GEV distribution for the Rijeka station compared with the heavy rain episode on September 12th, 2012. The maximum precipitation amounts for the heavy episode over intervals of 20,30, and 40 min were especially intense, and they could only be expected once in a thousand, several hundred, and a hundred years, respectively - rainfall amounts of this magnitude are exceptionally rare. The maximum amounts that fell during the intervals of 2 and $4 \mathrm{~h}$ can be expected once in 40 and 59 years, respectively, so they are rare incidents. 


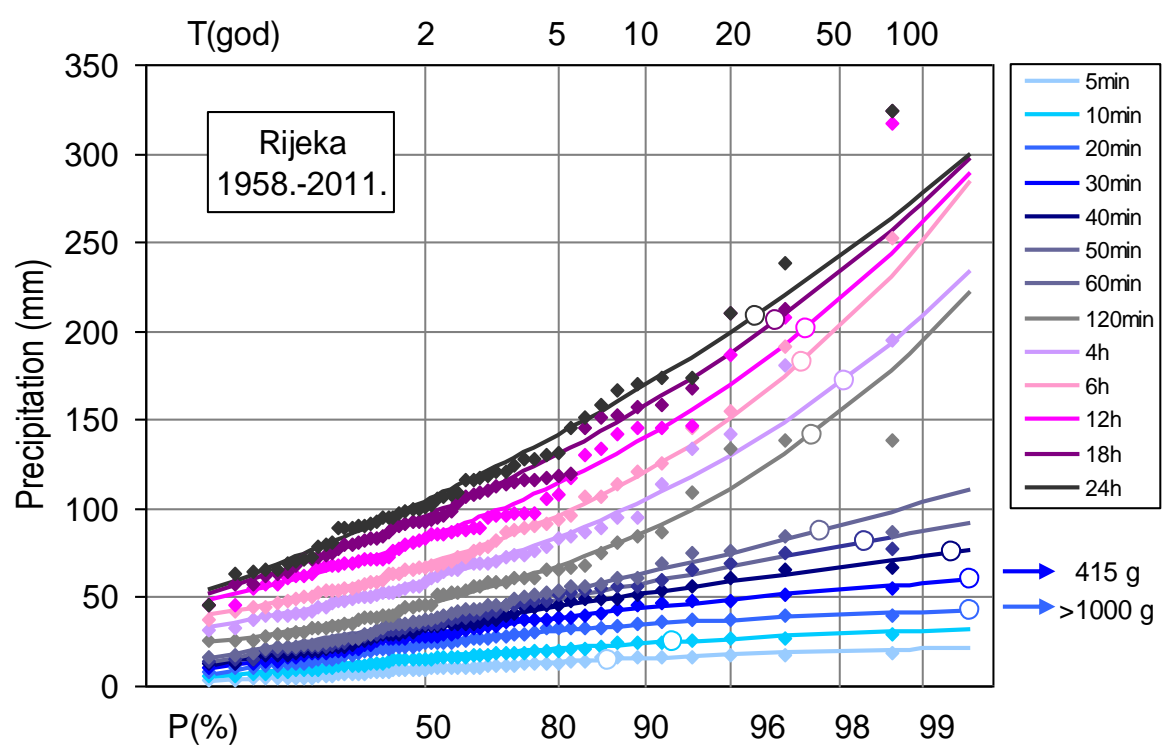

Figure 5 Annual short-term precipitation amounts in 1958-2011 (rhombuses) compared with the rain episode on September $12^{\text {th }} 2012$ (circles)

\subsection{Estimation of maximum short-term precipitation amounts for Rijeka (1958-2012)}

The rain episode in September 2012 in Rijeka was extreme for very short intervals of 20 minutes to 2 hours (Table 2), producing rainfall amounts greater than any since the beginning of recording in 1958. Because of this episode, it is important to update the maximum short-term precipitation estimates because they are used as an input value in planning and design of urban drainage systems. Table 3 and Figure 6 show the new calculations for the Rijeka station. Mostly, the changes in estimates are positive, even for return periods longer than 20 years, and they increased by $5-13 \%$ for the intervals from 20 minutes to 12 hours. The coefficient of variation, as a measure of interannual variability, increased by $1-2 \%$ for the intervals of 20 minutes to 18 hours. According to new assessment, the September maxima in 2012 for the intervals from 20 to 50 minutes still stand out as extremely rare events, which can be expected once every 40 to 135 years (Table 2). For the other intervals, the recorded maxima have probabilities of occurring equal to or slightly greater than those listed in the earlier estimates. Figure 6 shows the annual short-term precipitation amounts according to the GEV distribution.

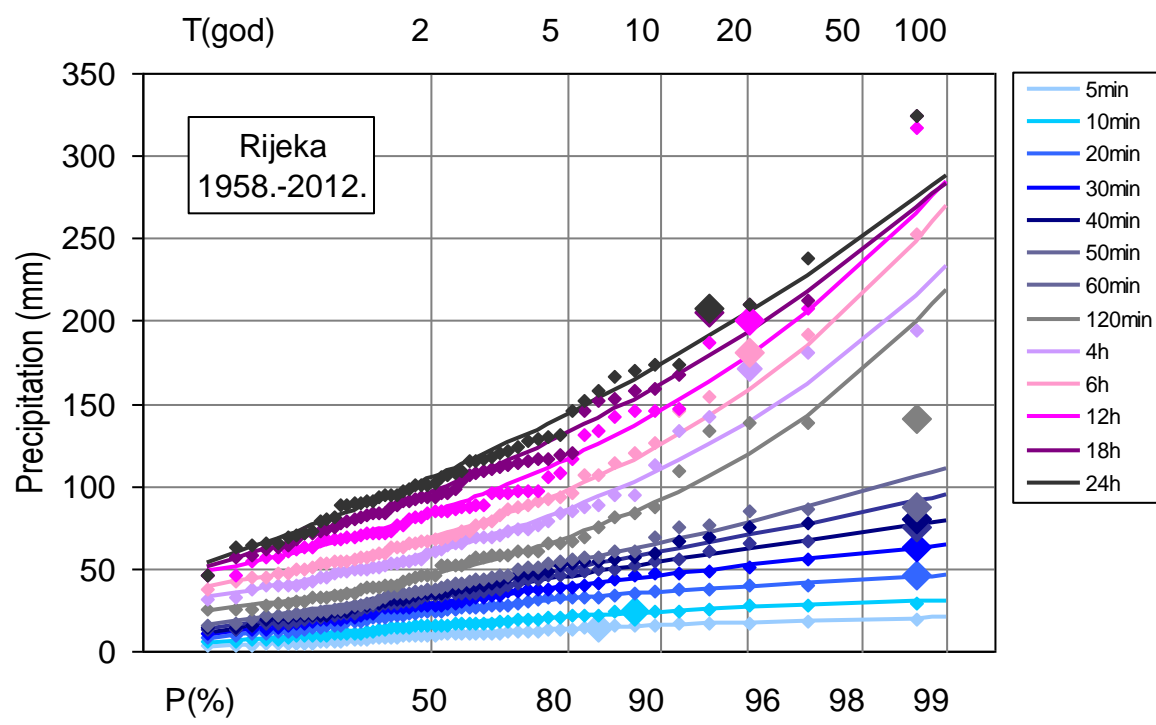

Figure 6 Annual short-term precipitation amounts in 1958-2012 (small rhombuses) and the precipitation amounts for the rain episode on September $12^{\text {th }}, 2012$ (large rhombuses) 


\subsection{IDF curves}

Using the estimates of maximum precipitation calculated from the annual maximum series for 1958-2012 (Table 3 ), we calculated the rainfall intensities $i(\mathrm{~mm} / \mathrm{min}$ ) for intervals of 10 to $120 \mathrm{~min}$ (Table 4). The IDF curves show the functional link between precipitation intensity, duration, and frequency (return period). This relationship lets one calculate the rainfall intensity, not just for discrete durations from 10-120 min (in increments of $10 \mathrm{~min}$ ), as presented in Table 4, but also for any duration up to 2 hours. The best adjustment to rainfall intensities for the Rijeka station for return periods of $2,5,10,20,50$, and 100 years is given by the power function $i^{\prime}=a t^{b}$, where $a$ and $b$ are constants that depend on the characteristics of precipitation regime over the area, and $t$ is the interval over which the precipitation is studied. Using the rainfall intensity and the associated duration $t$, we determined the constants $a$ and $b$ by the least-squares method. For return periods of $2,5,10,20,50$, and 100 years, we added the $i^{\prime}$ to the rainfall intensities. Figure 7 shows the IDF curves for the city of Rijeka.

\section{Table 3 Maximum precipitation amounts $(\mathrm{mm})$ over different intervals $t$ and return periods $\mathrm{T}$ (year) according to the GEV distribution for Rijeka in T1958-2012}

\begin{tabular}{|c|c|c|c|c|c|c|}
\hline \multirow{2}{*}{$\boldsymbol{t}$} & \multicolumn{7}{|c|}{ Return period (year) } \\
\cline { 2 - 7 } & $\mathbf{2}$ & $\mathbf{5}$ & $\mathbf{1 0}$ & $\mathbf{2 0}$ & $\mathbf{5 0}$ & $\mathbf{1 0 0}$ \\
\hline $\mathbf{5} \mathbf{~}$ in & 9.7 & 13.4 & 15.4 & 17.1 & 19.1 & 20.3 \\
\hline $\mathbf{1 0} \mathbf{~ i n}$ & 15.5 & 20.8 & 23.7 & 26.1 & 28.8 & 30.6 \\
\hline $\mathbf{2 0} \mathbf{~}$ in & 23.8 & 31.6 & 35.8 & 39.4 & 43.2 & 45.7 \\
\hline $\mathbf{3 0} \mathbf{~}$ in & 28.6 & 39.1 & 45.7 & 51.6 & 58.9 & 64.0 \\
\hline $\mathbf{4 0} \mathbf{~}$ in & 32.5 & 45.3 & 53.6 & 61.5 & 71.5 & 78.9 \\
\hline $\mathbf{5 0} \mathbf{~}$ in & 35.2 & 49.8 & 60.0 & 70.1 & 83.8 & 94.4 \\
\hline $\mathbf{6 0} \mathbf{~}$ in & 37.3 & 53.4 & 65.4 & 77.9 & 95.8 & 110.7 \\
\hline $\mathbf{2} \mathbf{~ h}$ & 46.0 & 69.3 & 91.2 & 119.1 & 168.4 & 218.8 \\
\hline $\mathbf{4} \mathbf{~}$ & 59.6 & 86.0 & 109.5 & 138.1 & 186.3 & 233.2 \\
\hline $\mathbf{6} \mathbf{~}$ & 68.4 & 97.8 & 124.4 & 157.3 & 213.7 & 269.3 \\
\hline $\mathbf{1 2} \mathbf{~}$ & 83.6 & 116.6 & 145.0 & 178.4 & 233.0 & 284.3 \\
\hline $\mathbf{1 8} \mathbf{~}$ & 96.0 & 132.5 & 161.3 & 193.1 & 241.3 & 283.4 \\
\hline $\mathbf{2 4} \mathbf{~}$ & 104.9 & 143.9 & 173.3 & 204.7 & 250.2 & 288.4 \\
\hline
\end{tabular}

We tested the correlation between the rainfall intensity calculated with the IDF curve $i^{r}$ and the rainfall intensity obtained from the estimated maximum precipitation amount $i$ by assessing the correlation coefficient $r$. Table 5 shows the equations we obtained for selected return periods and the associated correlation coefficients. Higher correlation coefficients indicate a better adjustment of the IDF curve. However, note that, although these coefficients show high correlation (Table 5), the intensities obtained from the IDF curves for return periods of 2 and 10 years for intervals of 10 and 120 minutes vary by $9-10 \%$ from the intensities obtained from the estimated maximum precipitation amounts (Table 4). This scattering is also shown in Figure 7. We recommend using the maximum precipitation amounts (Table 3) and the intensities obtained from them (Table 4), instead of the IDF curves $i^{\prime}$ (Table 5), which introduce additional error by joining the curve to calculated results [20]. 
Table 4 Rainfall intensities $i(\mathrm{~mm} / \mathrm{min})$ obtained from the maximum precipitation amounts (Table 3 ) and calculated rainfall intensities $i^{\prime}(\mathrm{mm} / \mathrm{min})$ from the IDF curves (Rijeka, 1958-2012)

\begin{tabular}{|c|c|c|c|c|c|c|c|c|c|c|c|c|}
\hline \multirow{2}{*}{$t(\min )$} & \multicolumn{2}{|c|}{2 years } & \multicolumn{2}{|c|}{5 years } & \multicolumn{2}{|c|}{10 years } & \multicolumn{2}{|c|}{20 years } & \multicolumn{2}{|c|}{50 years } & \multicolumn{2}{|c|}{100 years } \\
\hline & $i$ & $i^{\prime}$ & $i$ & $i^{\prime}$ & $i$ & $i^{\prime}$ & $i$ & $i^{\prime}$ & $i$ & $i^{\prime}$ & $i$ & $i^{\prime}$ \\
\hline 10 & 1.55 & 1.69 & 2.08 & 2.21 & 2.37 & 2.45 & 2.61 & 2.61 & 2.88 & 2.73 & 3.06 & 2.78 \\
\hline 20 & 1.19 & 1.15 & 1.58 & 1.55 & 1.79 & 1.79 & 1.97 & 1.99 & 2.16 & 2.24 & 2.29 & 2.40 \\
\hline 30 & 0.95 & 0.91 & 1.30 & 1.26 & 1.52 & 1.49 & 1.72 & 1.70 & 1.96 & 1.99 & 2.13 & 2.20 \\
\hline 40 & 0.81 & 0.77 & 1.13 & 1.09 & 1.34 & 1.30 & 1.54 & 1.52 & 1.79 & 1.83 & 1.97 & 2.07 \\
\hline 50 & 0.70 & 0.68 & 1.00 & 0.97 & 1.20 & 1.18 & 1.40 & 1.40 & 1.68 & 1.71 & 1.89 & 1.98 \\
\hline 60 & 0.62 & 0.62 & 0.89 & 0.88 & 1.09 & 1.09 & 1.30 & 1.30 & 1.60 & 1.63 & 1.84 & 1.90 \\
\hline 120 & 0.38 & 0.42 & 0.58 & 0.62 & 0.76 & 0.79 & 0.99 & 1.00 & 1.40 & 1.33 & 1.82 & 1.64 \\
\hline
\end{tabular}

Table 5 IDF curves $i^{\prime}$ for selected return periods T with correlation coefficients $r$

\begin{tabular}{|c|c|c|}
\hline $\boldsymbol{T}$ (years) & IDF curve $(\mathrm{mm} / \mathbf{m i n}), \boldsymbol{t}(\mathbf{m i n})$ & $\boldsymbol{r}$ \\
\hline $\mathbf{2}$ & $i^{\prime}=6.22 t^{-0.565}$ & 0.991 \\
\hline $\mathbf{5}$ & $i^{\prime}=7.21 t^{-0.513}$ & 0.994 \\
\hline $\mathbf{1 0}$ & $i^{\prime}=6.97 t^{-0.454}$ & 0.997 \\
\hline $\mathbf{2 0}$ & $i^{\prime}=6.37 t^{-0.388}$ & 1.000 \\
\hline $\mathbf{5 0}$ & $i^{\prime}=5.33 t^{-0.290}$ & 0.987 \\
\hline $\mathbf{1 0 0}$ & $i^{\prime}=4.52 t^{-0.212}$ & 0.925 \\
\hline
\end{tabular}

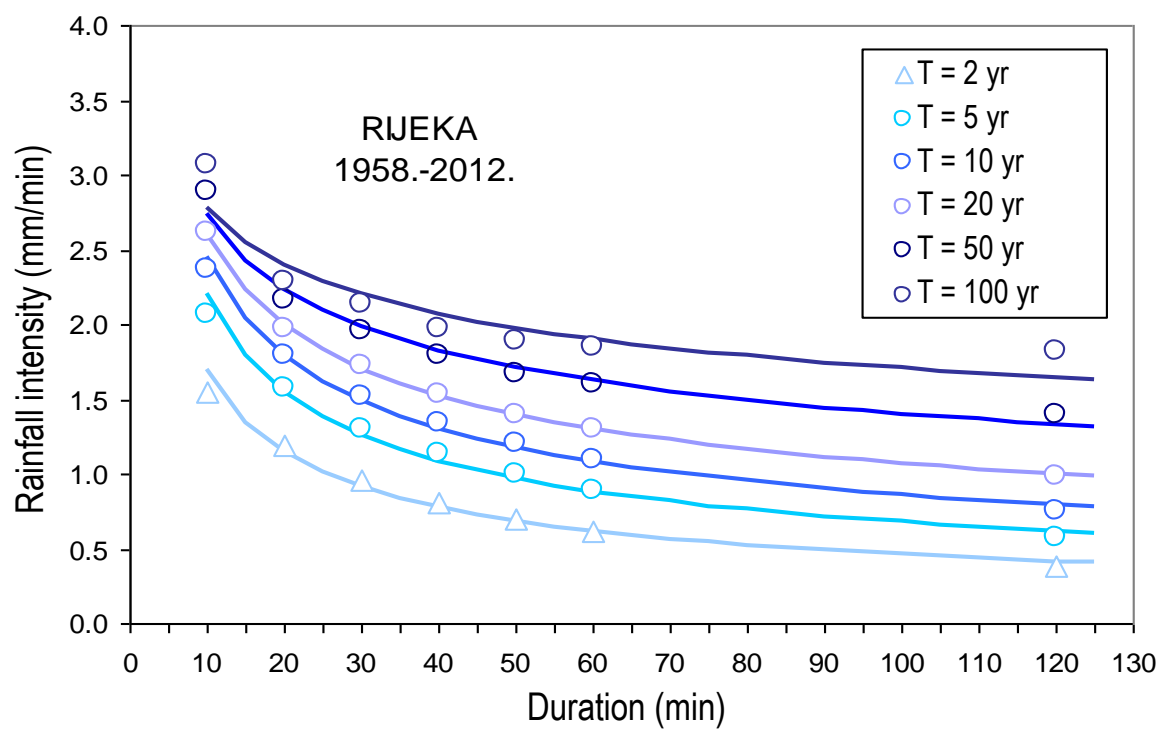

Figure 7 IDF curves for Rijeka for various return periods 


\section{CONCLUSIONS AND GUIDELINES}

The heavy rainfall episode on September 12th, 2012 in the Rijeka region initiated an assessment of its frequency and intensity, based on statistical analysis applied to the long-term precipitation data series. From an analysis of the annual cycle of maximum short-term precipitation frequency, they occur in the Rijeka region mostly in the autumn (September, October, and November). We assessed the precipitation amount over various short-term intervals according to the estimated maxima, which were based on a long-term data series from a time period preceding the observed event. These results show that the September 12th, 2012 event produced an extraordinarily rare intensity of rainfall for durations of 20 to 40 minutes, and a rare intensity of rainfall for durations of 2 and 4 hours.

Using the longest available data series, a time period of 55 years, we produced a new assessment of the expected maximum annual short-term precipitation amounts for different occurrence probabilities (i.e., return periods). We calculated IDF curves for durations of 10 to 120 minutes and return periods of 2, 5, 10, 20, 50, and 100 years, done by applying the annual maximum series of precipitation parameters as input data for the GEV distribution. We used these calculations to update the input hydrological values used for hydraulic engineering calculations. Further analysis should review adjustments to the theoretical distribution that use annual maxima on new, longer data series-for example, one that uses a transgression series as input data to calculate the maximum short-term precipitation events (e.g., the general Pareto distribution). Comparing these results with the current calculations would improve assessments of the probability for heavy short-term precipitation events.

Analyzing temporal changes in precipitation, especially of precipitation extremes, is important to studying climate change [21, 22]. Besides the standard indices of precipitation extremes [23, 24], other extreme precipitation values, such as those analyzed in this paper, can be used in hydraulic engineering design, planning, and adjustment to climate changes. However, these analyses are extremely demanding, both when detecting changes in recorded data and even more when simulating present and future climate because of the resolution of a regional model. These analyses are outside the scope of the current paper, but they should be included in further research related to hydraulic engineering. In fact, defining the IDF curves for specific locations is a good starting point for modern calculations of urban drainage. However, because of the large spatial and time variability of extreme short-term rainfall, this data does not usually suffice for defining a "design storm." Thus, further research and models must assess the maximum rainfall intensity in specific regions.

\section{Acknowledgment}

The research presented in this paper is a part of a bilateral Croatian and Japanese project "Risk Identification and Land-Use Planning for Disaster Mitigation of Landslides and Floods in Croatia". This work has also been supported in part by Ministry of Science, Education and Sports of the Republic of Croatia under the project "Hydrology of Sensitive Water Resources in Karst" (114-0982709-2549) and in part by Croatian Science Foundation under the project 2831 (CARE).

\section{References}

[1] Perčec Tadić, M.; Gajić-Čapka, M.; Zaninović, K.; Cindrić, K. 2014: Drought Vulnerability in Croatia, Agric. Conspec. Sci., Volume 79, Issue 1, pp. 31-38.

[2] Penzar, B.; Penzar, I.; Orlić, M. 2001: Vrijeme i klima hrvatskog Jadrana (Weather and Climate of the Croatian Adriatic), Dr. Feletar \& Hrvatski hidrografski institut, Zagreb-Koprivnica-Split (in Croatian).

[3] Bonacci, O. 1994: Oborine - glavna ulazna veličina u hidrološki ciklus, Geing, Split (in Croatian).

[4] Gajić-Čapka, M.; Horvat, M. 2009: Regionalne razlike jakih kratkotrajnih oborina u Istri, Hrvatske vode, Volume 68, Issue 17, pp. 87-101 (in Croatian).

[5] Rubinić, J.; Gajić-Čapka, M.; Milković, J.; Ožanić, N. 1995: Intenziteti oborine - problemi obrade i interpretacije u praksi. Okrugli stol: Uloga hidrologije u strukturi gospodarstva Hrvatske, 20. travnja 1995., Zbornik radova, pp. 53-69 (in Croatian).

[6] Građevinski fakultet Rijeka 2008: Osnovna analiza oborinskih značajki i izrada programske podrške za arhiviranje i pretraživanje oborinskih podataka s oborinskih postaja JKP „Vodovoda i kanalizacije“; Rijeka - I faza, (voditelj Josip Rubinić) Rijeka (in Croatian). 
[7] IGH - PC Rijeka 1999: Studija kanalizacijskog sustava grada Rijeke, Rijeka, not published (in Croatian).

[8] Građevinski fakultet Rijeka 2002: Idejni projekt uređenja Škurinjskog potoka uzvodno od stacionaže 2+760.00), (Nevenka Ožanić), Rijeka, not published (in Croatian).

[9] Ožanić N.; Rubinić J. 1998: Problemi urbane odvodnje pri pojavama ekstremnih oborina. Zbornik radova Znanstvenog skupa Andrija Mohorovičić - 140. obljetnica rođenja, Zagreb, pp. 417-425 (in Croatian).

[10] Gajić-Čapka, M. 1999: Duljina normalnog niza za kratkotrajne oborine u Hrvatskoj, Hrvatske Vode, Volume 29, Issue 7, pp. 217-235 (in Croatian).

[11] Jenkinson, A. F. 1955: The frequency distribution of the annual maximum (or minimum) values of meteorological elements. Quart. J. R. Met. Soc., Volume 87, pp. 158-171.

[12] Jenkinson, A. F. 1969: Statistics of Extremes, Estimation of Maximum Floods. World Meteorological Organisation, Geneve, WMO Technical Note No. 98, Chapter 5.

[13] Coles, S. 2001: An Introduction to Statistical Modelling of Extreme Values, Springer, London.

[14] Klein Tank, A. M. G.; Zwiers, F. W.; Zhang, X. 2009: Guidelines on analysis of extremes in a changing climate in support of informed decisions for adaptation, World Meteorological Organisation, WMO-TD No. 1500, WCDMP-No. 72.

[15] Sevruk, B.; Geiger, H. 1981: Selection of distribution types for extremes of precipitation, World Meteorological Organisation, Geneva, Operational Hydrology, Report No. 15, WMO - No. 560, p. 64.

[16] Faragó, T.; Katz, R. W. 1990: Extremes and Design Values in Climatology, World Meteorological Organisation, WMO-TD-No. 386, WCAP-No.14, p. 46.

[17] Durrans, S. R.; Brown, P. A. 2000: Development of an Internet-Based Rainfall Atlas for Alabama, 5th Int. Workshop on Precipitation in Urban Areas, Pontresina, Switzerland. 10-12 December 2000, IHP-V, Preprints of Papers, p. 2631.

[18] Gajić-Čapka, M.; Cindrić, K.; Mihajlović, D. 2008: Oborina / Precipitation, Klimatski atlas Hrvatske/Climate Atlas of Croatia 1961-1990, 1971-2000. Državni hidrometeorološki zavod / Meteorological and Hydrological Service of Croatia (DHMZ), Zagreb, pp. 41-57 (in Croatian).

[19] Novi list, www.novilist.hr, 13.9.2014.

[20] Gajić-Čapka M. 2002: Regionalna analiza učestalosti ekstremnih oborina, Okrugli stol: Urbana hidrologija, Split, 25. i 26. travnja 2002, pp 91-100 (in Croatian).

[21] Gajić-Čapka, M.; Cindrić, K. 2011: Secular trends in indices of precipitation extremes in Croatia, 1901-2008, Geofizika, Volume 28, Issue 2, pp. 293-312.

[22] Gajić-Čapka, M.; Cindrić, K.; Pasarić, Z.: Trends in precipitation indices in Croatia, 1961-2010, Theor. Appl. Climatol. (submitted).

[23] Peterson, T. C.; Folland, C.; Gruza, G.; Hogg, W.; Mokssit, A.; Plummer, N. 2001: Report on the activities of the Working Group on Climate Change Detection and Related Rapporteurs 1998-2001. World Meteorological Organization Rep. WMO-TD No 1071, WCDMP-No 47, Geneva, Switzerland.

[24] WMO 2004: Report of the CCI/CLIVAR expert team on climate change detection, monitoring and indices (ETCCDMI), WCDMP - No 54. 